\title{
In vitro study on role of $\sigma B$ protein in avian reovirus pathogenesis
}

\author{
Manas R. Praharaj ${ }^{1}$, Aditya P. Sahoo ${ }^{4}$, Tapan K.S. Chauhan ${ }^{1}$, Ravi Kumar Gandham ${ }^{1}$, \\ Shikha Saxena ${ }^{1}$, Ravi K. Agarwal' ${ }^{2}$ Kuldeep Dhama ${ }^{3}$, Bina Mishra ${ }^{1}$, Asok K. \\ Marriappan ${ }^{3}$, Ashok K. Tiwari ${ }^{1}$, Puroshottam Prasad Goswami ${ }^{1}$, Bishnu Prasad \\ Mishra $^{1}$ and Deepak Kumar ${ }^{1}$

\footnotetext{
${ }^{1}$ Division of Veterinary Biotechnology, Indian Veterinary Research Institute, Izatnagar, Uttar Pradesh, India

${ }^{2}$ Division of Livestock Product Technology, Indian Veterinary Research Institute, Izatnagar, Uttar Pradesh, India

${ }^{3}$ Avian Disease Section, Division of Pathology, Indian Veterinary Research Institute, Izatnagar, Uttar Pradesh, India

${ }^{4}$ ICAR- Directorate on Foot and Mouth Disease, Mukteshwar, Nainital, Uttarakhand, India
} \\ Correspondence to: Deepak Kumar, email: deep_biotek@yahoo.com, deepak_bt@ivri.res.in \\ Keywords: avian reovirus; 33 gene; $\sigma B$ protein; microarray; arthritis \\ Received: December 26, $2017 \quad$ Accepted: February 23, $2018 \quad$ Published: April 13, 2018 \\ Copyright: Praharaj et al. This is an open-access article distributed under the terms of the Creative Commons Attribution License \\ 3.0 (CC BY 3.0), which permits unrestricted use, distribution, and reproduction in any medium, provided the original author and \\ source are credited.
}

\section{ABSTRACT}

Avian reoviruses, members of Orthoreovirus genus was known to cause diseases like tenosynovitis, runting-stunting syndrome in chickens. Among eight structural proteins, the proteins of S-class are mainly associated with viral arthritis but the significance of $\sigma B$ protein in arthritis is not established till date. In this infection pathological condition together with infection of joints often leads to arthritis because joints consists of cartilage which forms lubricating surface between two bones, and has limited metabolic, replicative and repair capacity.

To establish the role of $\sigma B$ protein in arthritis, an in-vitro microarray study was conducted consisting four groups viz. virus infected and control; pDsRed-Express-N1$\sigma B$ and empty pDs-Red transfected, CEF cells. With cut-off value as FC $\geq 2$, $p$ value $<0.05,6709$ and 4026 numbers of DEGs in virus and $\sigma B$, respectively were identified. The Ingenuity Pathway Analysis gave an idea about the involvement of $\sigma B$ protein in "osteoarthritis pathway", which was activated with z-score with 3.151. The pathway "Role of IL-17A in arthritis pathway" was also enriched with -log (p-value) 1.64. Among total 122 genes involved in osteoarthritis pathway, 28 upregulated and 11 downregulated DEGs were common to both virus and $\sigma B$ treated cells. Moreover, 14 upregulated and 7 downregulated were unique in $\sigma B$ transfected cells. Using $q R T-$ PCR for IL-1B, BMP2, SMAD1, SPP1 genes, the microarray data was validated. We concluded that during ARV infection $\sigma B$ protein, if not fully partially leads to molecular alteration of various genes of host orchestrating the different molecular pattern in joints, leading to tenosynovitis syndrome.

\section{INTRODUCTION}

ARV belongs to the family Reoviridae, genus Orthoreovirus. Reoviridae, a family of viruses which can affect the gastrointestinal tract as well as respiratory tract was first isolated from the respiratory and enteric tract of humans and animals but was not associated with the disease the name reovirus was used. The name is actually mnemonic for respiratory (r) enteric (e) orphan (o) virus. Genotype 1 reoviruses in poultry cause a severe joint condition popularly known as stunting and runting syndrome. Cartilage occupies an intermediate developmental state, as most bone develops from cartilage, but some cartilage is specifically arrested in this process (ossification) to provide the stable adult tissue. Chondrocytes are the only cell type within cartilage, secreting and enveloping themselves in a complex 
extracellular matrix mainly composed of type II collagen, aggrecan, hyaluronan, lubricin, and fibronectin.

The genome and protein compositions of ARV are generally similar to those of mammalian reovirus (MRV), the prototype of the orthoreovirus genus [1, 2]. However, some biological properties of the ARVs differ from mammalian reovirus, e.g. the lack of haemagglutination activity [3], the ability to induce fusion of cultured cells [4] and their pathogenicity towards their natural hosts. The avian reovirus genome expresses at least 12 primary translation products, of which 8 are structural proteins $(\sigma \mathrm{A}, \sigma \mathrm{B}, \sigma \mathrm{C}, \lambda \mathrm{A}, \lambda \mathrm{B}, \lambda \mathrm{C}, \mu \mathrm{A}$, and $\mu \mathrm{B})$ that become incorporated into progeny reovirions, other two, $\mu \mathrm{BN}$ and $\mu \mathrm{BC}$, originate by post-translational cleavage of their precursor $\sigma \mathrm{B}[5]$ and the other four proteins ( $\mu \mathrm{NS}, \sigma \mathrm{NS}$, p17 and p10) are non-structural, as they are not found in mature reovirions, but expressed in infected cells $[6,7]$. $\sigma B$ protein produces group specific antibody against virus which plays an important role in viral pathogenesis [8].

Several methods for diagnosis of ARVs are reported [9, 10]. Additionally, virus isolation [11], immunofluorescent staining [12] and immunoperoxidase histochemistry $[13,14]$ offer the straight detection of viral antigens in tendon tissues. The methods for detection of ARV RNA from the cell culture [15] or from both cell cultures and tendon specimens [16] have been developed to provide a sensitive tool for the laboratory diagnosis. The serological diagnosis methods such as ELISA were also used for detection of serum antibodies in large number of samples simultaneously [17-20]. Molecular level diagnosis techniques include routine PCR [21, 22], multiplex PCR [23], reverse transcription loop-mediated isothermal amplification assay (RT-LAMP) [24], real time probe based loop mediated isothermal amplification (RTCy5 qLAMP) [25] etc.

The previous studies reported about the tenosynovitis/arthritis [26-28] and osteoporosis [29] induced by avian reovirus in younger stage of broiler poultry. Lameness in turkeys has sometimes been reported to be associated with avian reoviruses, but experimental evidence from the USA indicates the presence of novel reoviruses causing arthritis and tendon rupture clinically identical to that in chickens [30]. This disease causes acute lameness of bird affecting tibiotarsal-tarsometatarsal joint (hock joint), the main load-bearing joint of bird. The affected joints are swollen with rupture of gastrocnemius muscle in severe case accompanied with haemorrhage causing green colouration of skin at the joint. The main reason of mortality in birds is due to reduced growth and feed conversion.

Previously, the gene expression profiles of vero cells upon ARV S1133 infection and ARV-encoded proapoptotic protein $\sigma \mathrm{C}$ over-expression was examined using microarray [31]. Further, a number of high throughput sequencing studies came in recent past. Identification and complete genome sequencing of two naturally occurring
ARV variant strain co-infections having same M2 segment but were distantly evolved nine other segments in layer chickens using NGS was achieved [32]. Most recently, a gene expression RNA-Seq study showed that inoculation of chicken fibroblast DF-1 cells lines with ARV stimulates a prolonged antiviral response in host cells and interferes with cell growth and cell death pathways [33]. Despite many studies towards its diagnosis and pathogenesis induced by ARV, no study signifies the role of various genes of arthritis pathway expression in $\mathrm{ARV}$ and $\sigma \mathrm{B}$ protein induced pathogenesis, which was the main objective of our study. For this, microarray along with IPA analysis was used with predesigned microarray chip to signify the probable mechanism of ARV and $\sigma B$ protein induced arthritic molecular changes. In this study, we analyzed changes in the expression of cellular genes in chicken embryo fibroblasts (CEFs) infected with the ARV DVB02 strain and $\sigma \mathrm{B}$ transfection using microarray analysis. Analysis and functional studies of these genes and the relevant pathways may provide novel information that will increase our understanding of the pathogenesis of ARV and the mechanisms of in-vitro host responses.

\section{RESULTS}

\section{Cloning confirmation and time course expression of pDsRed-Express-N1- $\sigma B$ in CEF cell}

The schematic overview of the microarray experiment is shown (Figure 1). The CEF adapted ARV field isolate (DVB02) available in the laboratory was revived and propagated under sterile conditions. The RNA was isolated; cDNA was synthesized. The $\sigma B$ gene was amplified at $1.1 \mathrm{kbp}$ (Figure 2a) using S3based PCR amplification by primers shown in Table 1 . HindIII and BamHI double digested pDsRed-Express-N1 expression vector and PCR amplified $\sigma \mathrm{B}$ gene were ligated, transformed in E. coli cells and plated on LB agar plate. The colonies were selected and the recombinants were screened by colony PCR and further confirmed by double digestion by HindIII and BamHI which released the desired fragment of $1.1 \mathrm{kbp}$ (Figure 2b). The selected recombinant clone was abbreviated as pDsRed-Express$\mathrm{N} 1-\sigma \mathrm{B}$. The plasmid DNA from the clone was transfected in $70-80 \%$ confluent cells in a four well plate using Lipofectamine 2000 (Invitrogen, USA) and cells were kept at $37^{\circ} \mathrm{C}$ in $5 \% \mathrm{CO}_{2}$ concentration. Samples were collected at $24,48,72 \mathrm{~h}$ post transfection of pDsRed-Express$\mathrm{N} 1-\sigma \mathrm{B}$ and infection of ARV. After harvesting the cells from tissue culture plate, lysis of cells was done using mammalian protein extraction reagent (Genetix, India) according to manufacturer's protocol. Further, SDS-PAGE and western blot analysis showed the expression of $42 \mathrm{kDa}$ $\sigma \mathrm{B}$ protein using SPF chicken raised hyperimmune serum (Figure 2c). Optimum $\sigma \mathrm{B}$ protein expression and virus titre was observed at $48 \mathrm{~h}$ post transfection which was 
further confirmed at transcript level by Real Time PCR analysis of $\sigma \mathrm{B}$ transcripts. Thus, $48 \mathrm{~h}$ post transfection was chosen as suitable time point for microarray experiment.

\section{Gene expression profiling in ARV infected and $\sigma B$ transfected cells}

The dysregulated genes were identified taking Paired t-test for statistical analysis (fold change $\geq 2$ and $\mathrm{p}$ value $<0.05$ ). A total of 3841 genes were upregulated and 2868 downregulated in ARV infected cells, whereas 2194 were upregulated and 1832 downregulated in $\sigma B$ transfected cells.

\section{Prediction of canonical networks and DEGs activation}

The IPA analysis was done by taking - log ( $\mathrm{p}$-value) threshold at 1.3 and $\mathrm{z}$-score at 2 . Taking apoptosis, cellular immune response, humoral immune response and pathogenesis into consideration activated canonical pathways of $\sigma \mathrm{B}$ transfected cells were predicted and most of them were related to pathogenesis and apoptosis revealing the catastrophic effect of $\sigma \mathrm{B}$ in host (Figure $3 \mathrm{a}$ ). Venn diagram of differentially expressed genes (DEGs) is shown in (Figure 3b). The most important prediction that was shown was the activation of osteoarthritis pathway with z-score 3.151 , which was correlating with

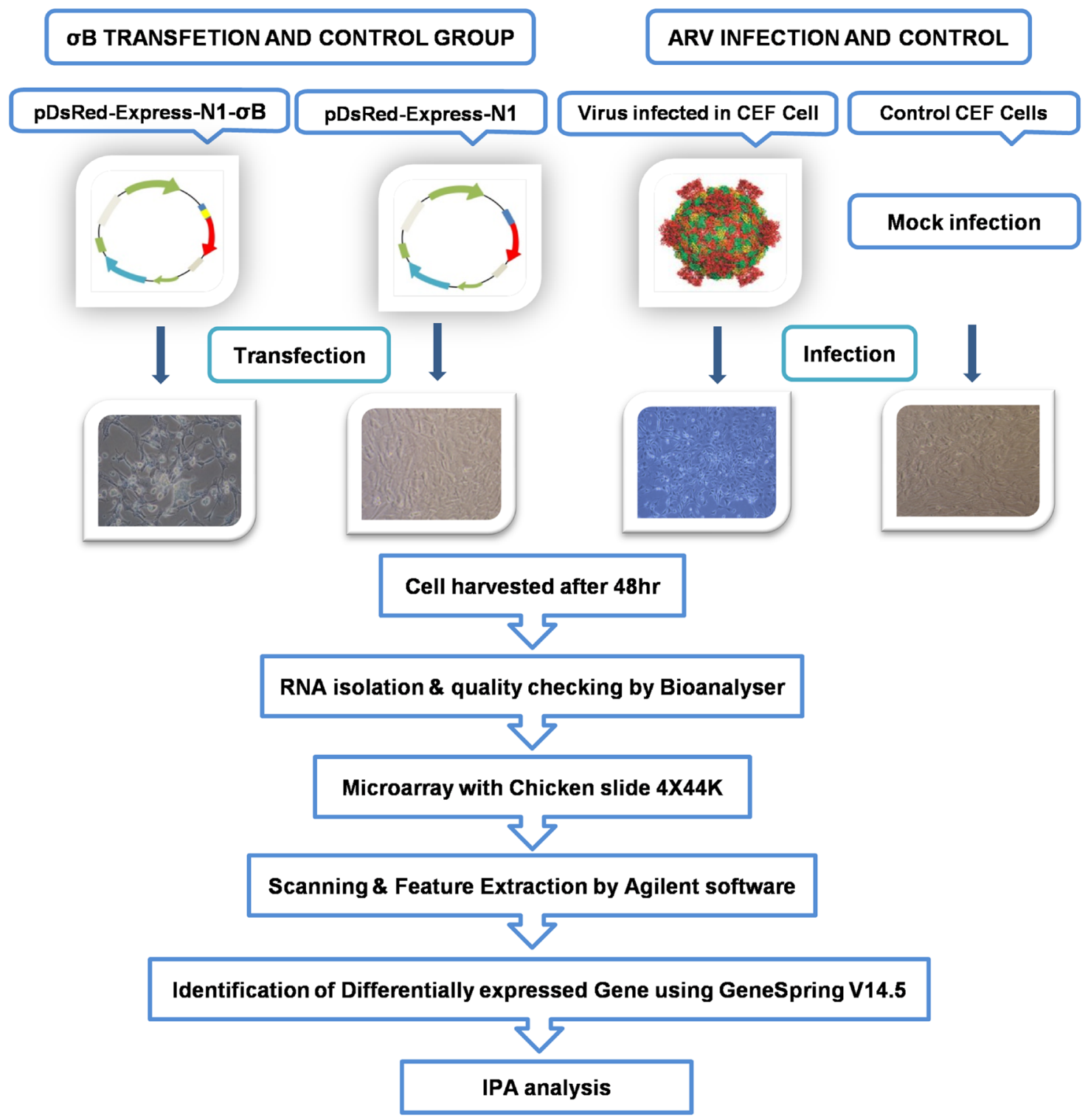

Figure 1: Schematic representation of workflow of microarray experiments for delineating osteoarthritic pathways in $A R V$ and $\sigma B$ treated CEF cells. 
the previous research finding i.e. association of ARV in teno-synovitis syndrome (Figure 4a). The other enriched pathways like "Role of IL-17A in Arthritis" with -log (p-value) 1.64 also validated the association of $\sigma B$ in arthritis.

\section{Analysis of expression of upstream regulators of osteoarthritis pathway}

IPA analysis showed the inhibition and activation of molecules that causes arthritis in poultry. Casp 1 and Casp14 were upregulated in both virus and $\sigma \mathrm{B}$ treated group which showed the activation of apoptosis that may lead to activation of osteoarthritis. Likewise upregulation of ANK2, in both the groups was predicted to inhibit MYBBP1, which was leading to development of osteoarthritis by NF- $\kappa \mathrm{B}$ activation through activation of IL-1 $\beta$ similar to activation of TLR2 by upregulated fibronectin. Additionally, activation of MMP13 by SP7 led to activation of cartilage catabolism with HTRA1. Moreover SOX9 predicted to inhibit aggrecan directly or indirectly through inhibition of HIF $1 \alpha$ that activates cartilage catabolism was found to be downregulated. $\mathrm{NF}-\kappa \mathrm{B}$ complex played a vital role in progression of osteoarthritis through RELA and VCAM1 which was linked with osteoarthritis as a precursor [34]. The predicted pathway (Figure 4b) also correlated the Histone
Deacetylase 2 (HDCA2) with IL6 and MMP9 and RELA which was seem to be boost the progression of osteoarthritis by repressing cartilage specific gene [35]. The previous experiment suggested the involvement of IL6 in osteoarthritis progression through MMP13 [36], which is further established in current study showing IL6 as upregulated DEG in both virus and $\sigma \mathrm{B}$ treated group.

\section{Comparison analysis}

Among total 122 DEGs of osteoarthritis pathway, 28 upregulated and 11 downregulated DEGs were common to both virus treated and $\sigma \mathrm{B}$ transfected cells. Moreover 14 upregulated and 7 downregulated were unique in $\sigma B$ transfected cells. The common DEGs showed association of $\sigma \mathrm{B}$ in osteoarthritis in relation to ARV. However, two genes in $\sigma B$ transfected cells have reverse pattern of regulation (Up to down \& down to up regulation) than ARV infected cells (Figure 3b).

\section{Protein-protein interaction network among the differentially expressed genes}

Predicted DEHC networks of proteins involved in activated osteoarthritis pathway in virus infected and $\sigma \mathrm{B}$ transfected cells are shown. The network analysis in $\sigma \mathrm{B}$ transfected cells showed the interaction between the major

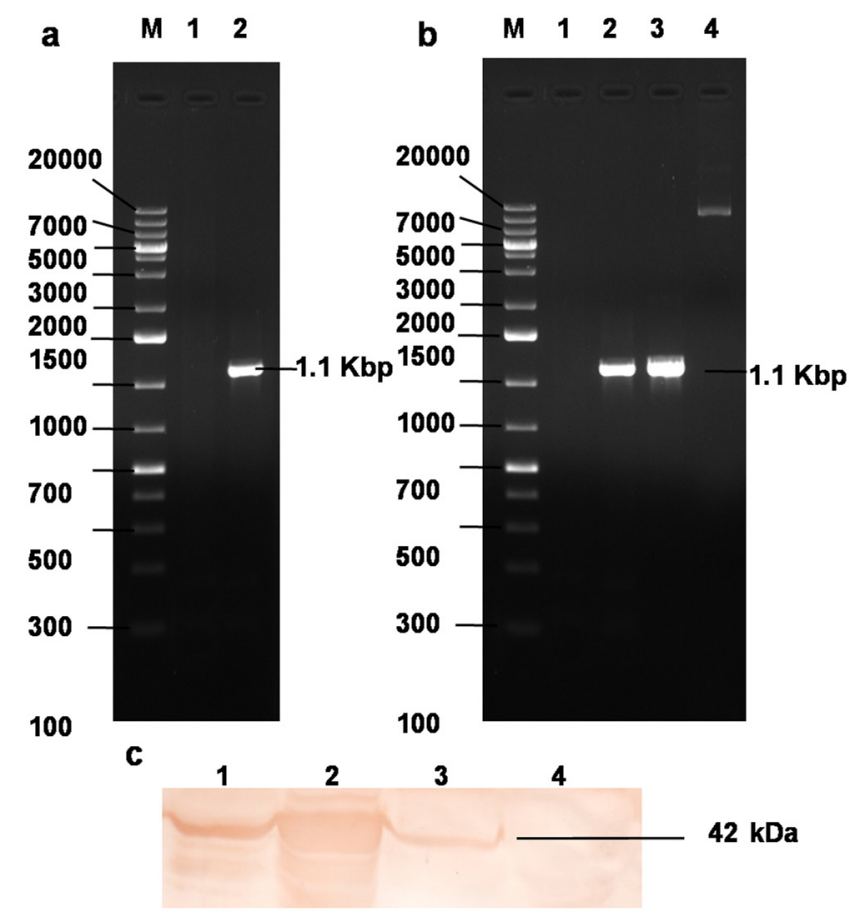

Figure 2: Cloning and expression of recombinant $\sigma \mathrm{B}$ protein. (a) PCR amplification of ARV $\sigma \mathrm{B}$ gene. Lane M: $1 \mathrm{~Kb}$ plus DNA ladder, Lane 1: NTC, Lane 2: $\sigma \mathrm{B} 1104$ bp PCR product; (b) Lane M: $1 \mathrm{~Kb}$ plus DNA ladder, Lane 1: NTC, Lane 2-3: colony PCR yielding $\sigma \mathrm{B} 1104 \mathrm{bp}$ PCR product; Lane 4: Plasmid construct pDsRed-Express-N1- $\sigma \mathrm{B}$; (c) Western blot analysis using hyperimmune sera rose against recombinant $\sigma \mathrm{B}$ protein in SPF chicken. Lane 1: $24 \mathrm{~h}$, Lane 2: E. coli expressed $\sigma \mathrm{B}$ protein, Lane 3: $48 \mathrm{~h}$, Lane 4: $72 \mathrm{~h}$ post pDsRed-Express-N1- $\sigma \mathrm{B}$ plasmid transfection CEF cell lystae showing expressed eukaryotic $\sigma \mathrm{B}$ protein. 
Table 1: List of the genes and their forward \& reverse primers

\begin{tabular}{|c|c|c|c|}
\hline Gene & Primer sequence & Accession number & Product length (bp) \\
\hline \multirow[t]{2}{*}{ SPP1 } & F 5'-CGAAGATCGCCACAGCATTG-3' & NM_204535 & $137(860-996)$ \\
\hline & R 5'-CAAACACACGTCGCTATGGC-3' & & \\
\hline \multirow[t]{2}{*}{ BMP2 } & F 5'-ATGACGTGGGGTGGAATGAC-3' & NM_204358 & $164(905-1068)$ \\
\hline & R 5'-GCAAGCCTTGGGGATTTTGG-3' & & \\
\hline \multirow[t]{2}{*}{ SMAD1 } & F 5'-TGGAATGCTGCGAGTTTCCT-3' & NM_001201455 & $138(317-454)$ \\
\hline & R 5'-GGCTGTGCTGAGGGTTGTAT-3' & & \\
\hline \multirow[t]{2}{*}{ IL1B } & F 5'-CGCTTCATCTTCTACCGCCT-3' & NM_204524 & $144(666-809)$ \\
\hline & R 5'-GATGTTGACCTGGTCGGGTT-3' & & \\
\hline \multirow[t]{2}{*}{$\beta$-actin } & F 5'-CGTGCTGTGTTCCCATCTATC-3' & L08165 & $219(150-368)$ \\
\hline & R 5'-CTCCTCAGGGGCTACTCTCAG-3' & & \\
\hline \multirow[t]{2}{*}{$\begin{array}{l}\sigma B \text { gene for eukaryotic } \\
\text { expression }\end{array}$} & $\begin{array}{l}\text { F 5'-GCAAGCTTGCCACC ATGGAGGT } \\
\text { ACGTGTGCCAAACTTTC -3' }\end{array}$ & KX421250 & $1104(1-1104)$ \\
\hline & $\begin{array}{l}\text { R 5'-GCGGATCC TTACCAACCACAC } \\
\text { TCCACAACAGTG -3' }\end{array}$ & & \\
\hline \multirow[t]{2}{*}{$\sigma \mathrm{B}$ gene for qRT-PCR } & F-5'-GGAGGTACGTGTGCCAAACT-3' & KX421250 & $150(3-152)$ \\
\hline & R-5'-CAACAATACGCATTGCCAAC-3' & & \\
\hline
\end{tabular}

qRT-PCR using $\beta$-actin as internal control experiment was used for validation of arthritic mechanism of ARV $\sigma \mathrm{B}$ protein as revealed by microarray.

proteins viz. EP300, CREBBP, SMAD1, SOX9 that were downregulated and TGFB1, NFKB2, RELA, SMAD6, CASP1, IL1B that were upregulated (Figure 5b). EP300 and CREBBP were found to be major hubs with degree 384 and 254, respectively. RELA was highly connected upregulated gene with degree 231 and found to be connected with NFKB2, CREBBP and EP300. CREBBP, important for chondrogenesis was highly connected with SMAD1, which was mostly associated with chondrocytes differentiation. In virus, EP300 and CREBBP was also downregulated and highly connected with degree 447 and 292 respectively. RELA was upregulated and connected with degree 265 (Figure 5a).

\section{Validation of microarray data by qRT-PCR}

Microarray analysis data of ARV infected cells (Figure 6a) and $\sigma \mathrm{B}$ transfected cells (Figure 6b) were validated by using primers of 4 important candidate genes (SPP1, BMP2, SMAD1 and IL1B) that were involved in osteoarthritis pathway. $\beta$-actin was used as endogenous control. The results of the qRT-PCR validation were in concurrence with the microarray results.

\section{DISCUSSION}

ARVs belongs to orthoreovirus genus of Reoviridae family. It has been found to be associated with tenosynovitis, runting-stunting syndrome of chickens [37]. It is a non-enveloped virus with icosahedral symmetry containing 10 genome segments. According to their electrophoretic mobility the genomic segments can be separated into large (L-class), medium (M-class), small segments (S-class). Most importantly s-class genome plays important role in inflammation, apoptosis and serodiagnosis. $\sigma \mathrm{B}$ protein is found to be more conserved than other S-class proteins among ARV genes [38], but yet there is no report signifying the of role of $\sigma \mathrm{B}$ in pathogenicity of ARV infection. This present in vitro study was carried out to examine pathogenesis related gene expression of host, in response to ARV infection and $\sigma \mathrm{B}$ transfection. $\sigma \mathrm{B}$ protein was specifically chosen and to elucidate its effect towards provoking pathogenesis in host vis-à-vis host response to virus. Insight into the signaling pathways and key signaling molecules involved in tissue level defense mechanisms against ARV infection can help to elucidate the response of the host to ARV infection.

Previously, it was reported that $\mathrm{ARV}$ and $\sigma \mathrm{C}$ protein induces DNA damage and this process involves ROS intermediates and signaling pathways associated with DDIT-3 and GADD45 $\alpha$ using microarray [31]. Another high throughput next generation sequencing study revealed whole genome sequence of two ARV isolates and established that the two co-infection strains showed close relationships in $\sigma \mathrm{A}, \sigma \mathrm{B}$ and $\sigma \mathrm{NS}$ genes [32]. Most recently a report identified that Wnt14 plays a pivotal role 
in initiating synovial joint formation in the chick limb, but the researchers were unable to determine the specific pathway that is responsible for the joint pathogenesis of ARV [39]. It was shown that the elevated expression of Wnt14 gene was observed, which might play a key role in the development of the disease [33]. The detailed study regarding the molecular arthritic pathogenesis and role of $\sigma \mathrm{B}$ protein in viral arthritis was still unknown. In our study, the Ingenuity ${ }^{\circledR}$ Pathway Analysis (IPA ${ }^{\circledR}$ ) was used for detailed study of pathways involved in osteoporosis. The detailed study was performed showing various pathways involved in up and down regulation of DEGs in ARV virus infected and $\sigma \mathrm{B}$ transfected chicken embryo fibroblast cells.

a

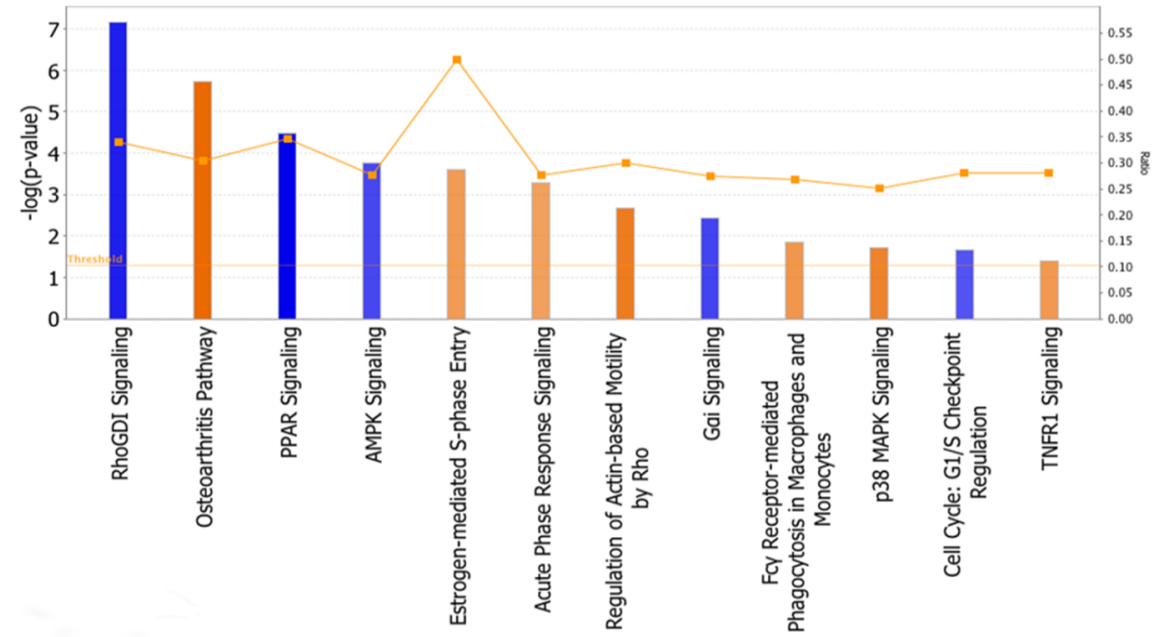

b

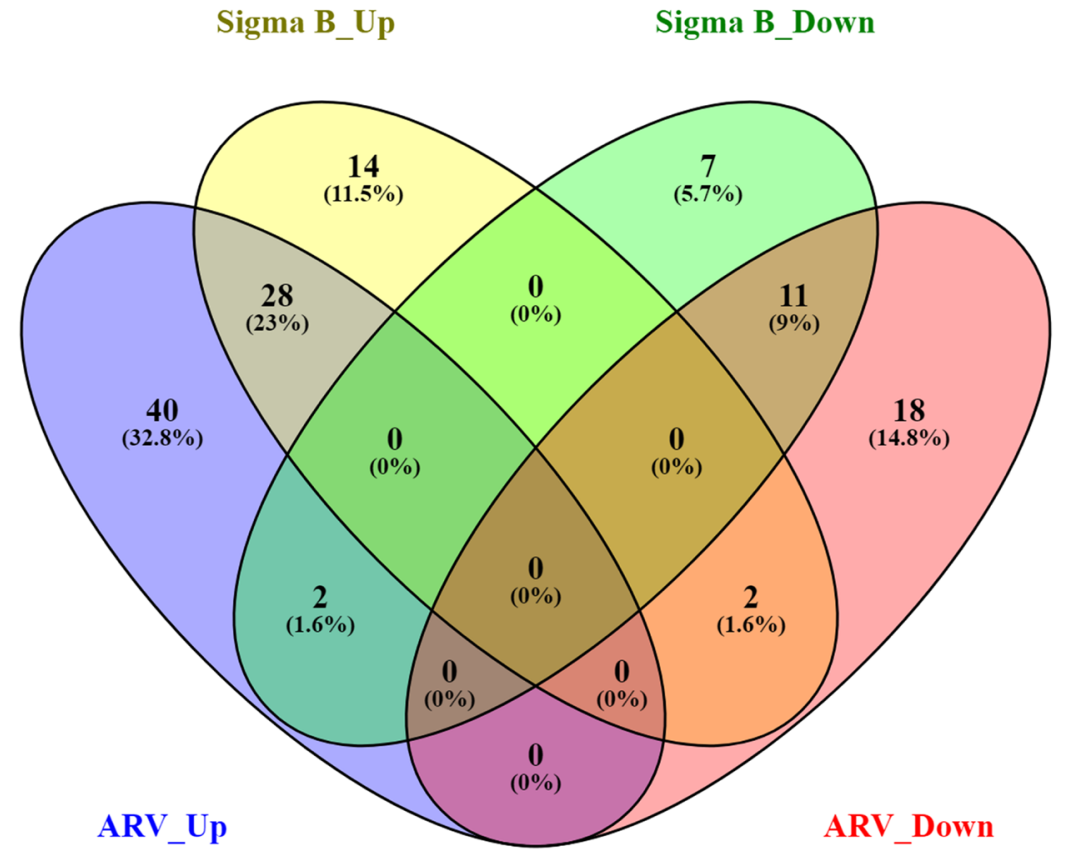

Figure 3: Activated canonical pathways in ARV infected and pDsRed-Express-N1- $\sigma$ B transfected groups. (a) Depicts the activated canonical pathways based on their z-score $\geq 2$ analysed through IPA, (b) Venn diagram of differentially expressed genes (DEGs). All DEGs are clustered into four comparison groups represented by four ellipses. The sum of all the figures in one ellipse represents the number of DEGs in one comparison group (e.g., ARV infected vs. $\sigma \mathrm{B}$ transfected). The overlapping parts of different ellipses represent the number of DEGs in common from those comparison groups. Diagram shows the upregulated and downregulated unique and common genes related to osteoarthritis pathway of both ARV infected and $\sigma \mathrm{B}$ transfected CEF cells. 
Despite of many studies towards diagnosis and pathogenesis induced by ARV, there was no study signifies the pathway of in $\mathrm{ARV}$ and $\sigma \mathrm{B}$ protein induced joint pathogenesis, which was the main objective of our study. One colour microarray based gene expression analysis experiment was performed and the differentially expressed genes in $\mathrm{ARV}$ infected and $\sigma \mathrm{B}$ plasmid transfected $\mathrm{CEF}$ cells were identified by analysing the feature extraction data using GeneSpring V14.5. Based on the (FC) $\geq 2$ and $\mathrm{p}$ value $<0.05$, the differentially expressed genes in both the groups were identified. In ARV infected vs control group 3841 DEGs were upregulated and 2868 DEGs were downregulated, where as in case of $\sigma \mathrm{B}$ transfected vs control group 2194 and 1832 DEGs were upregulated and downregulated respectively.

Osteoarthritis is the progressive degradation of joints such as knee, with an endpoint of pain and complete loss of function. During osteoarthritis also involves other tissues of the joint, such as synovial fibroblasts and immune cells. During osteoarthritis chondrocytes undergo complex changes, including extensive degradative enzyme secretion, hypertrophy, and apoptosis, along with the formation of osteophytes from other mesenchymal stem cells [40]. This closely resembles the normal developmental transition from cartilage to bone, which has thus served as a major focus and model of research into the molecular mechanisms of osteoarthritis. The pro-osteoarthritis pathways generate autocrine selfactivating loops in response to arthritic disease like ARV infection which can, unless countered by other events, can degrade cartilage to the point of symptomatic decline and destruction.

The major known molecular axes of osteoarthritis are the protective TGF $\beta$ to SOX9 pathway, which maintains cartilage, and the IL- $1 \beta$ and other inflammatory signals to RUNX2 pathway, which respond to inflammatory and damage signals to prompt repair, expression of degradative enzymes, and development

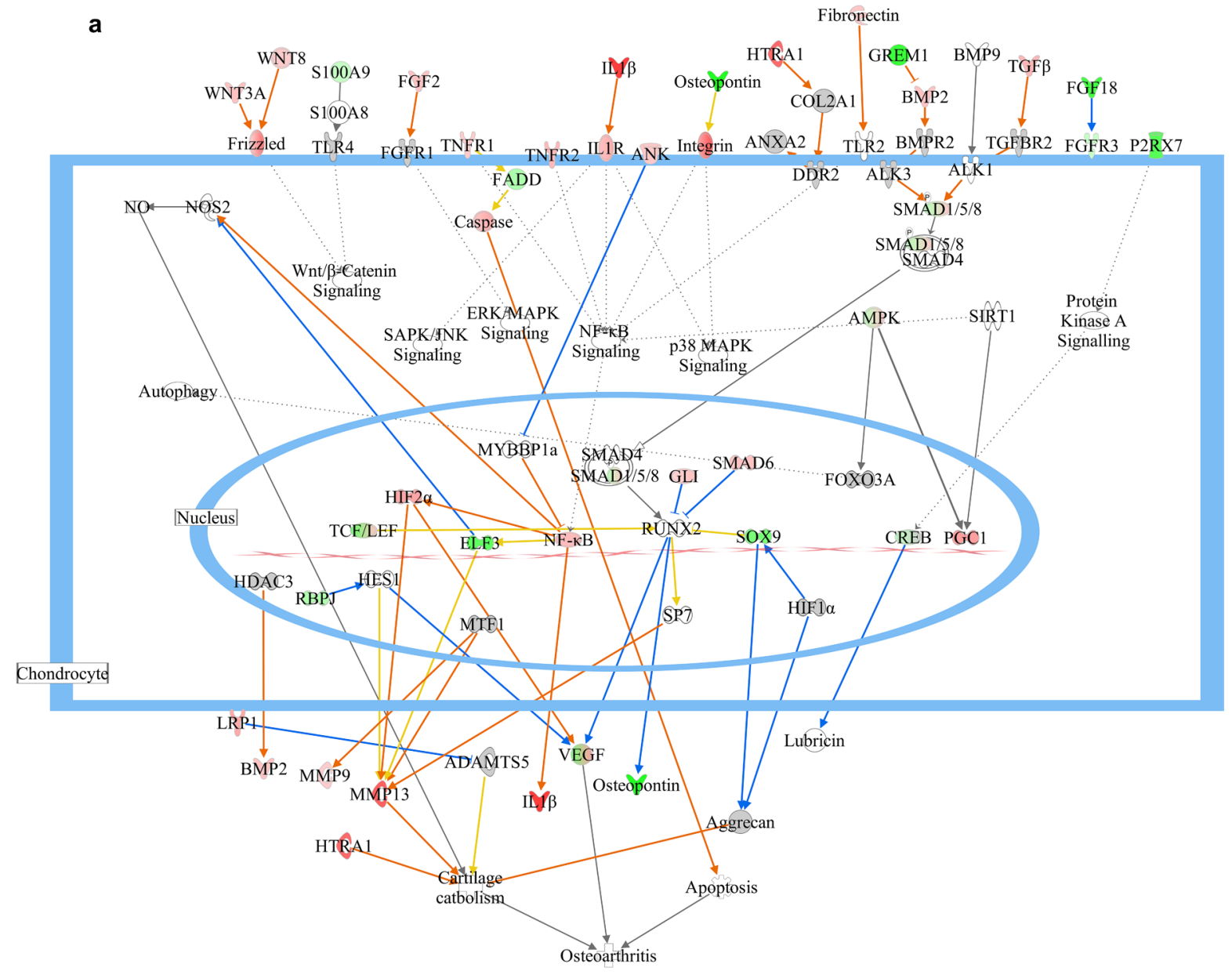

Figure 4: Delineated mechanism of osteoarthritis changes in response to $\sigma B$ protein (a) Pathway contains the differentially expressed genes related to ARV infected cells showing their mode of action and relation with each other in arthritis activation.

(Continued) 


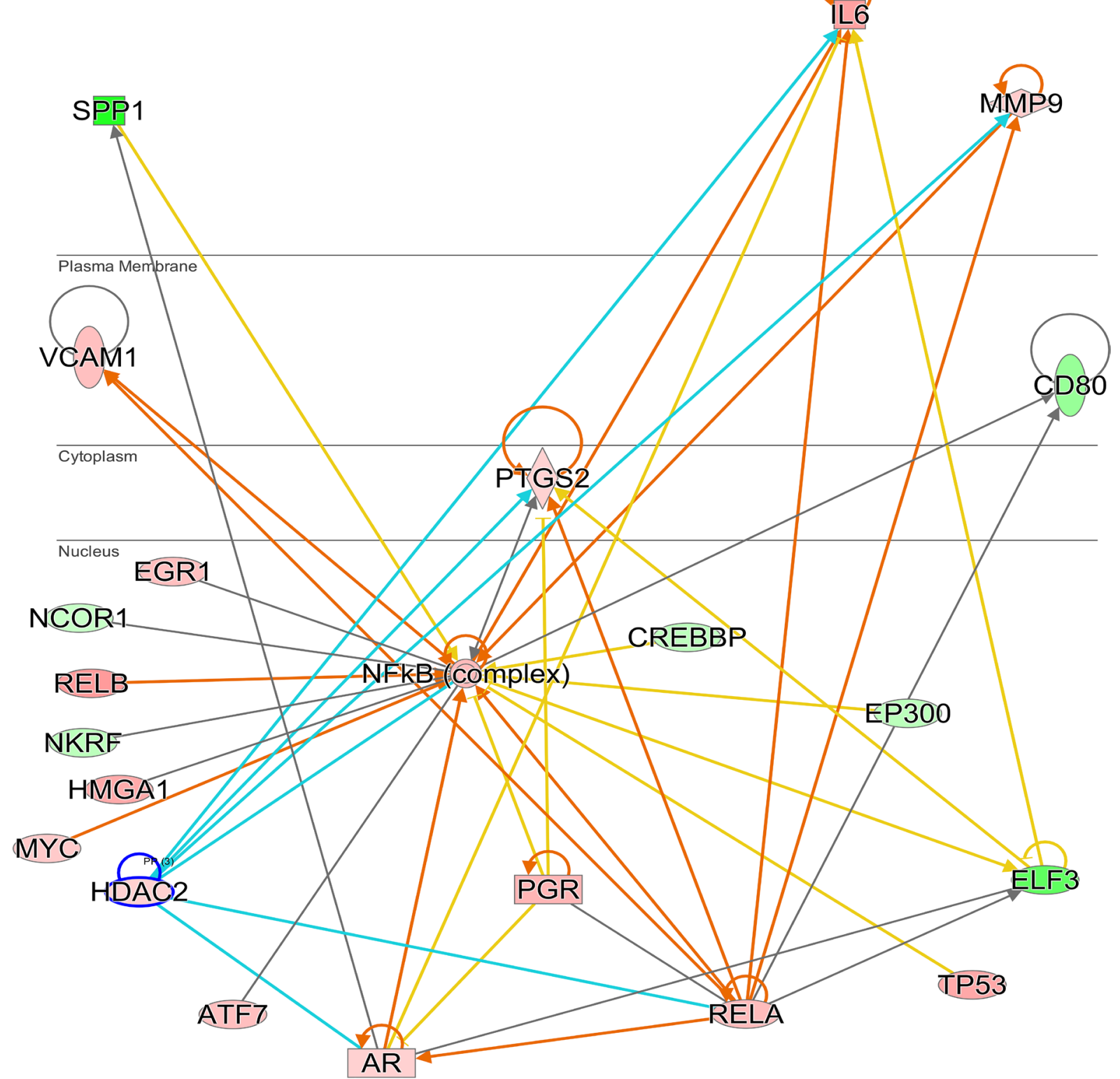

Figure 4 (Continued): (b) Predicted mechanism of arthritis induced by $\sigma \mathrm{B}$ protein by NFkB pathway and the up and down regulation of closely related genes of NFkB network. Red colour indicates the upregulation of particular gene and green colour indicates the downregulation of particular gene. Blue line indicates leads to inhibition and orange line indicates lead to activation and orange line indicates "finding inconsistent with state of downstream molecule".

towards bone including hypertrophy and apoptosis of chondrocytes. IL-1 $\beta$ was highly upregulated in $\sigma \mathrm{B}$ transfected cell with $4.57 \log 2$ (FC) showing increased inflammatory response, which suggested its catabolic effect on cartilage extracellular matrix along with TNF $\alpha$ [41]. Proinflammatory cytokines regulate the expression of a number of proteinases which destroy the extracellular cartilage [42]. Metalloproteinase and aggrecanases tend to degrade cartilage [43]. MMP-13, a matrix metalloproteinase expressed in osteoarthritis cartilage and causes collagen degradation, was upregulated in $\sigma \mathrm{B}$ treated group $[44,45]$ MMP2, was upregulated in both $\mathrm{ARV}$ and $\sigma \mathrm{B}$ treated group, is known as the most potent type II collagen degrading protein and along with MMP13. MMP-2 was also significantly detectable in late stage osteoarthritis [46]. Previous study reported the association of IL1RN with IL-1 $\beta$ in osteoarthritis, suggesting that the upregulation of IL1RN in $\sigma \mathrm{B}$ transfected cell, can increase the occurrence of osteoarthritis [47]. Moreover, IL-6 which was upregulated in both $\sigma \mathrm{B}$ transfected and virus infected 

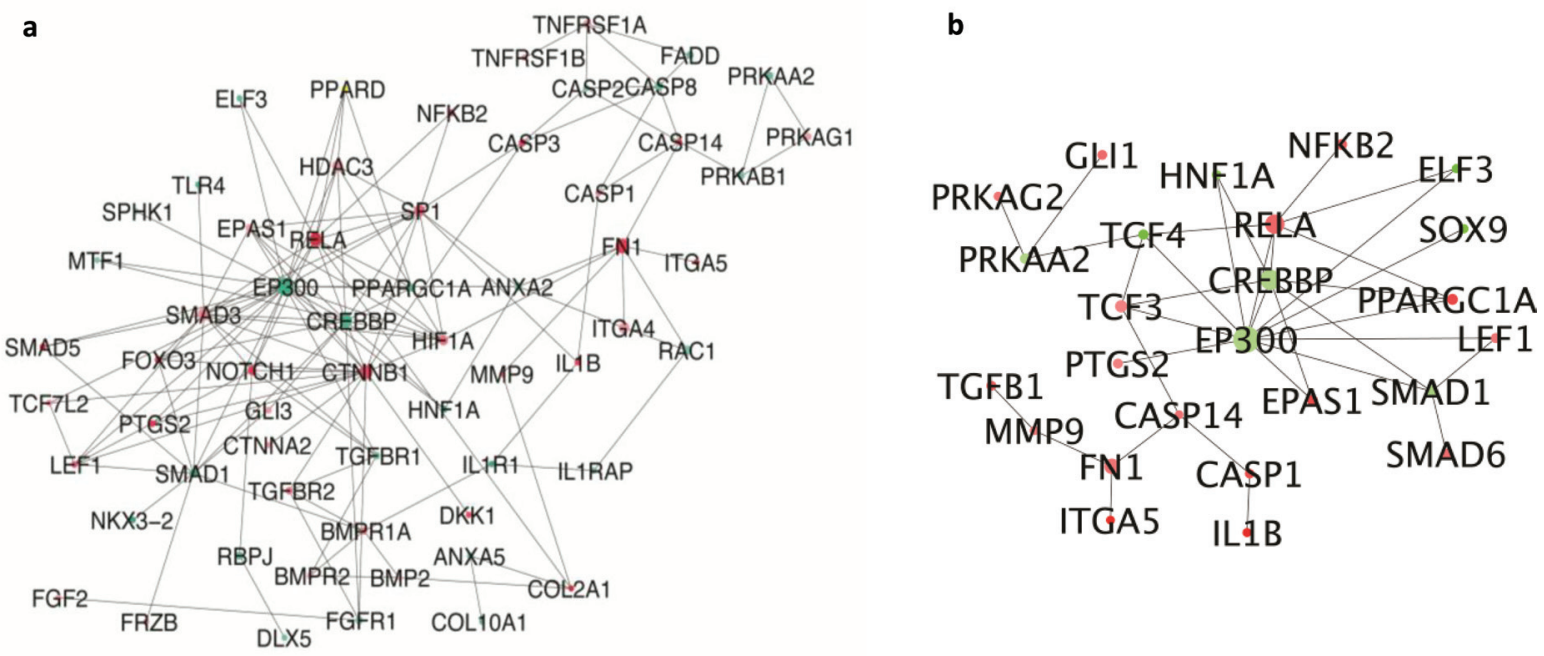

Figure 5: Interconnected network of differentially expressed osteoarthritis related genes (a) DEGs of ARV infected CEF cells compared to whole DEGs. Each circle indicating the node or member genes of the network are related to the hub i.e. with higher diameter than other arranged according to their degree; (b) DEGs of $\sigma \mathrm{B}$ transfected CEF cells compared to whole DEGs. Each circle indicating the node or member genes of the network are related to the hub i.e. with higher diameter than other arranged according to their degree.

a $\quad$ ARV infected cells

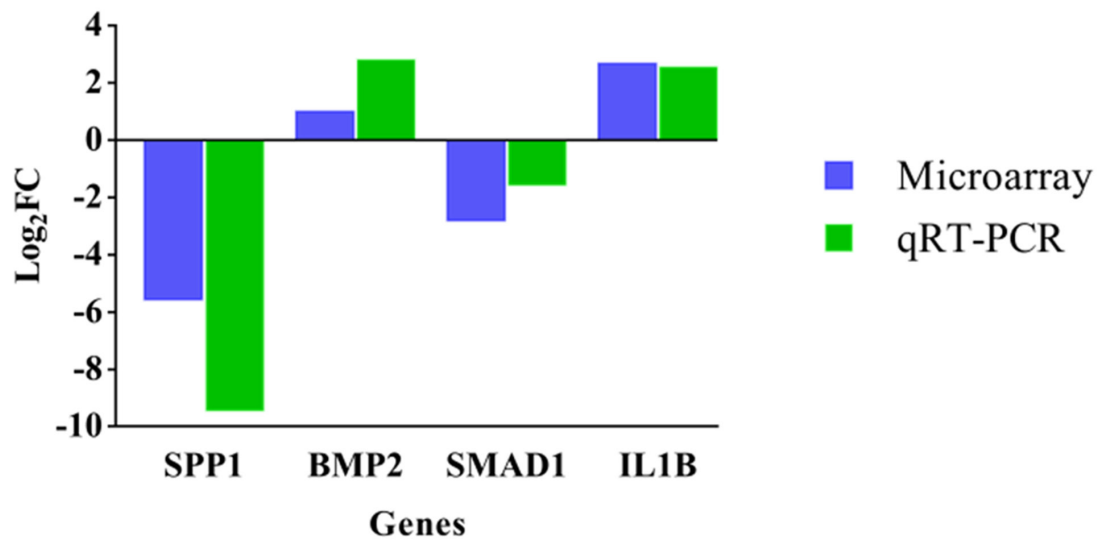

b

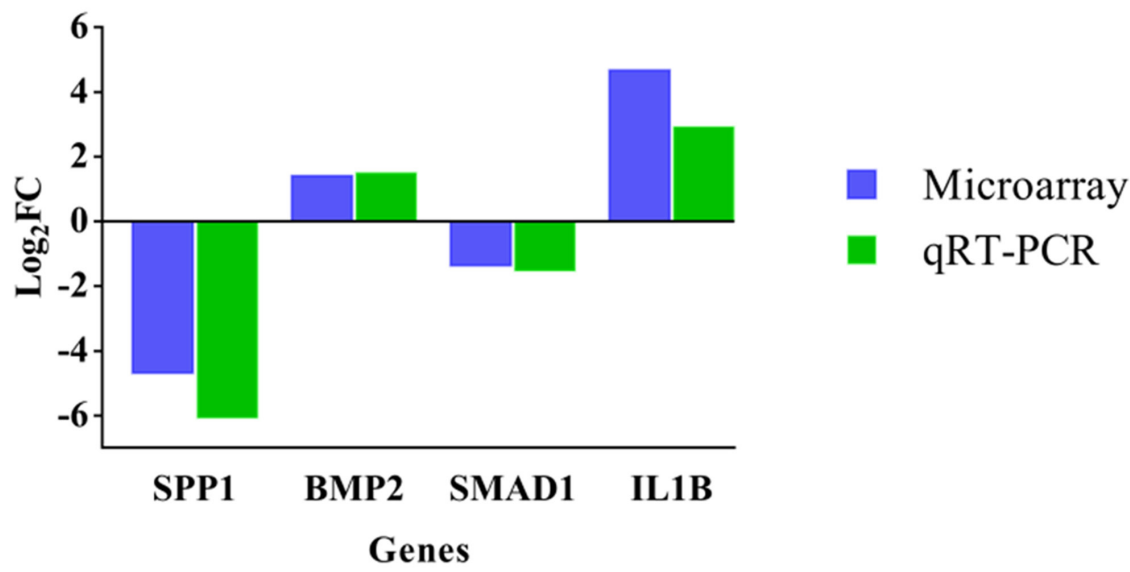

Figure 6: The Y-axis of the bar graph indicates the $\log 2$ fold changes of respective gene in ARV infected (a) and $\sigma \mathrm{B}$ transfected (b) $\mathrm{CEF}$ cells. cDNA derived from CEF cells at $48 \mathrm{hr}$ of infection/transfection was compared to respective control by qRT-PCR and microarray. 
cells, seems to be associated with osteoclastogenesis [48, 49] indicating its role towards arthritis stimulation.

Like IL-1 $\beta$, TGF- $\beta$ is a regulator of both anabolic and catabolic activity in joint. With combined effect, TGF- $\beta$ plays catabolic activity along with ESR 1 and its association was also seen in cartilage loss, enhanced matrix synthesis or adaptive responses of bone to degenerate cartilage [50]. The TGF- $\beta$ signalling induces arthritis through activation of ALK1, which acts through Smad $1 / 5 / 8$ pathway [51]. Also, estrogen association was studied with IL-1 $\beta$ for modulating the expression of MMPs [52]. The previous study also showed the association of MMP-13 expression with ALK1 expression suggesting them as key molecules of chondrocyte hypertrophy and osteoarthritis [53]. Similarly in our study, IL-1 $\beta$, TGF- $\beta$ were upregulated whereas Smad 1 is downregulated in both virus and $\sigma \mathrm{B}$ treated group leading to altered metabolism in joints leading to arthritic changes.

BMP which was upregulated in both virus and $\sigma \mathrm{B}$ treated groups is associated with condensation and chondrocyte differentiation through SOX9 expression through Smad pathway [54, 55]. Further, our data in $\sigma \mathrm{B}$ treated group showed downregulation in expression of SOX9 gene, a protective and stabilizing factor for chondrocytes, which glimpse towards activation of arthritis, which was also proofed by downregulation of $\mathrm{CEBP} / \mathrm{p} 300$ in virus infected group which was associated with chondrogenesis [56]. BMP signalling was studied to be inhibited by Smad6 [57] its upregulation in $\sigma \mathrm{B}$ treated group suggested its role in progression of arthritis. The upregulation of Smurf1 seems to boost the activity Smad6 and showed delay in endochondral ossification with Smad6 [58]. The experimental data suggested upregulation of Smurf1 both in ARV and $\sigma B$ treated groups. Association of Smurf1 with Smad6 inhibits Smad 1/5/8 signalling pathway (associated with BMP pathway) resulted in blocking BMP-2 induced chondrocyte hypertrophy and chondrocyte terminal differentiation terminating bone formation [59]. This hypothesis was also enlightened further with upregulation of COL9A2, which shows increase in its expression in arthritis [60] and TLR2, which will upregulate MMP increasing collagenolysis and aggrecanolysis [61, 62]. TLR2 was found to be upregulated in both virus and $\sigma \mathrm{B}$ treated group. Collectively, our study suggests the probable mechanism of joint pathogenesis in ARV infection and the role of $\sigma B$ gene in regulation of the arthritis pathway.

From this comprehensive study, we can conclude the molecular pattern of expression and activation of osteoarthritis pathway genes by ARV and its $\sigma \mathrm{B}$ protein. The current study, strengthen our understanding of the ARV induced joint pathogenesis and establishes the role of $\sigma \mathrm{B}$ protein in runting/stunting syndrome which in-turn may help in devising suitable treatment/control strategy for ARV infection.

\section{MATERIALS AND METHODS}

\section{Preparation of CEFs and virus propagation}

CEFs were freshly prepared from 10-day-old chicken embryos $[63,64]$ and were grown in DMEM (Gibbco) with 10\% fetal calf serum (FCS) for $\sim 24$ hours at $37^{\circ} \mathrm{C}$ under $5 \% \mathrm{CO}_{2}$ and then maintained at $5 \% \mathrm{FCS}$. The CEFs in 4 well plates were infected at a multiplicity of infection (MOI) 15 of ARV (DVB02) for $48 \mathrm{~h}$ at $37^{\circ} \mathrm{C}$ and $5 \% \mathrm{CO}_{2}$ and mock infected CEF cells in DMEM acted as control.

\section{Preparation of eukaryotic construct}

\section{Amplification of $\sigma B$ gene}

The $\sigma B$ gene for eukaryotic expression was amplified from Champion pET SUMO- $\sigma \mathrm{B}$ as template using specified primer set [25] with slight modification by introducing kozak sequence and HindIII and BamHI restriction enzyme site (Table 1). The PCR products were analyzed by $1.2 \%$ agarose gel electrophoresis after staining with Ethidium bromide $(0.5 \mu \mathrm{g} / \mathrm{ml})$ under Gel Doc System.

\section{Restriction enzyme digestion and cloning of $\sigma \mathrm{B}$ gene in pDsRed-Express-N1}

The PCR product was purified by QIAquick ${ }^{\circledR}$ Gel Extraction Kit (Qiagen, Germany) as per manufacture's protocol. The gel purified $\sigma B$ gene and pDsRedExpress-N1 vector was digested with HindIII and BamHI (NEB, USA) and ligated by T4 DNA ligase (NEB, USA) with standard protocol in 1:3 ratio of vector to $\sigma B$.

\section{Screening of $\sigma \mathrm{B}$ positive recombinants}

The ligated product was transferred into $E$. coli $\mathrm{DH} 5 \alpha$ strain by calcium chloride and heat shock transformation using a standard protocol. The transformed cells were plated on LB agar plates containing Kanamycin $(50 \mu \mathrm{g} / \mathrm{ml})$ and incubated overnight at $37^{\circ} \mathrm{C}$. The plates were observed for presence of colonies. For screening of positive recombinants the colony PCR was done with specified primer sets and protocols [25]. The PCR products were seen in $1.2 \%$ agarose electrophoresis with ethidium bromide $(0.5 \mu \mathrm{g} / \mathrm{ml})$ under Gel Doc System. The positive clone was again confirmed by restriction enzyme digestion with HindIII and BamHI.

\section{Transfection of recombinant plasmid in CEF cell}

pDsRed-Express-N1- $\sigma \mathrm{B}$ clones were transfected in $70-80 \%$ confluent cells in a four well plate using Lipofectamine 2000 (Invitrogen, USA) as per manufacturer's protocol with slight modification 
and kept for $48 \mathrm{~h}$ at $37^{\circ} \mathrm{C}$ and $5 \% \mathrm{CO}_{2}$. Western blot analysis was done to show the expression of $\sigma \mathrm{B}$ protein by taking out the cells from tissue culture plates using mammalian protein extraction reagent (Genetix, India) according to manufacturer's protocol. The western blot was performed with standard protocol with slight modification of blocking the membrane overnight with $5 \%$ skim milk in TBST at $4{ }^{\circ} \mathrm{C}$. The optimum dilution of chicken raised hyperimmune sera 1:200 and the HRP conjugated anti-chicken secondary antibody at 1:2000 for western blot was determined by checkerboard analysis.

\section{Experimental groups}

For microarray experiment the CEF cells were grown in 4 well plates. For virus treatment group cell culture wells in triplicate were infected at MOI 15 of ARV strain DVB02. Mock infected CEF cells in DMEM acted as control for virus treatment group.

For $\sigma \mathrm{B}$ treatment group cell culture wells in triplicate were transfected with $2.0 \mu \mathrm{g}$ of pDsRed-ExpressN1- $\sigma$ B construct using Lipofectamine 2000. Empty pDsRed-Express-N1plasmid transfected CEF cells were used as control for $\sigma \mathrm{B}$ transfection group. $\mathrm{CEF}$ cells for all the groups were kept for $48 \mathrm{~h}$ at $37^{\circ} \mathrm{C}$ in $5 \% \mathrm{CO}_{2}$ concentration. After $48 \mathrm{~h}$ of incubation the cells from three wells of each treatment and control group were harvested and pooled separately and subjected RNA isolation and RNA quality estimation using bioanalyzer. The experiment was repeated after a gap of few days and RNA collected from two independent experiments was subjected to microarray analysis.

\section{RNA isolation and array hybridisation}

RNAs were extracted using the RNeasy mini Kit (Qiagen, Germany) according to the manufacturer's protocol from 4 different groups as virus infected, control cells, pDsRed-Express-N1- $\sigma \mathrm{B}$ transfected cells and pDsRed-Express-N1 transfected cells. Sample RNAs were quantified using a NanoDrop ND-1000 and maintained at $-80^{\circ} \mathrm{C}$ for further use. For the microarray analysis, RNA quality was assessed using an Agilent Bioanalyzer (Agilent Technologies, USA). Sample RNA integrity numbers (RINs) were obtained to assign values to RNA measurements in an unambiguous manner. Total 200ng RNAs were reverse transcribed to produce doublestranded cDNA, from which cRNAs were synthesized and then labeled with cyanine-3-CTP. The labeled cRNAs were hybridized onto Agilent Chicken Gene Expression ( $4^{*} 44 \mathrm{~K}$, Design ID: 026441) microarrays [65]. After washing, the arrays were scanned using an Agilent SureScanner G2600D (Agilent Technologies, US). The sample labeling, microarray hybridization and washing were performed based on standard protocols provided by the Agilent Technologies, USA.

\section{Microarray data analysis}

To analyse array images, raw data were extracted using Feature Extraction software (version 11.5.1.1, Agilent Technologies) and then analyzed and normalized using the quantile algorithm. GeneSpring (version 14.5, Agilent Technologies, USA) was employed to perform a basic analysis of the raw data taking mock infected CEF cells as control for ARV infected cells and pDsRedExpress-N1 transfected cells as control for pDsRedExpress-N1- $\sigma \mathrm{B}$ transfected cells to normalize intensity and to give fold change. The microarray data have been submitted to the GEO database (http://www.ncbi.nlm. nih.gov/geo/) under accession number GSE103067. Differentially expressed genes were then identified based on fold-changes and P-values calculated using paired t-test. The threshold for up- and down-regulated genes was a fold change $>=2.0$ and a $P$ value $<0.05$.

\section{IPA analysis}

The DEGs of both groups were uploaded into QIAGEN's Ingenuity ${ }^{\circledR}$ Pathway Analysis (IPA, QIAGEN Redwood City, www.qiagen.com/ingenuity) and both core and comparison analysis was performed to identify canonical pathways, various upstream regulators such as transcription factors (TFs), mature microRNAs (miRNAs) and downstream effects pertaining to ARV infection by causal analysis approach which is based on the Ingenuity pathway knowledge base (IPKB) [66]. Fisher's exact test was used to calculate a p-value determining the significance of association between the differentially expressed genes and the canonical pathway. The significance was set at a p-value of 0.05 . In a network, two genes are considered to be connected if there is a path (line called as edge) in the network between them. The gene or gene products are referred to as nodes and the intensity of the node color indicates the degree of up- (red) or down(green) regulation of a given gene. Nodes are represented with various shapes to distinguish the functional class of the molecule. Labels on the edges describe the nature of the relationship between the nodes and genes. The n-value overlap p-value is computed based on significant overlap between genes in the dataset and known targets regulated by the transcriptional regulator.

\section{Protein-protein interaction network among the differentially expressed genes}

BioGRID (Biological General Repository for Interaction Datasets) is an online interaction repository with data compiled through comprehensive curation efforts. It provides a comprehensive resource of protein-protein and genetic interactions for all major model organism species [67]. All interaction data are freely provided through search index and available via download in a wide variety of standardized formats. In 
this repository, protein-protein interactions in chicken are chosen. Customized Perl scripts were used to find out interactions involving the differentially expressed genes. DEHC - DEHC were identified by taking the fold change file and the specified pathway related genes that were identified using IPA and the interaction network was visualized in Cytoscape 3.0.2 [68].

\section{qRT-PCR validation of microarray results}

After the RNA extraction according to manufacturer's instructions, $128 \mathrm{ng}$ RNA was reverse transcribed to cDNA with RevertAid Reverse transcriptase Kit (Invitrogen) according to the manufacturer's instructions. The qPCR validation was performed with SYBR green (Maxima SYBR green/ROX qPCR Master Mix (2X)). The target genes and their respective primers are listed in Table 1. Reaction mixes were prepared according to the manufacturer's instructions, and each sample was run in triplicate in the 7500 Fast RealTime qPCR machine (Applied Biosystems) with slight modification in annealing temperature at $58^{\circ} \mathrm{C}$.

The data obtained from the qRT-PCR was analyzed to calculate the fold change. The fold change of individual mRNA was calculated based on the $2^{-\Delta \Delta \mathrm{Ct}}$ method [69]. $2^{-\Delta \Delta \mathrm{Ct}}$ value obtained was converted to natural logarithmic scale to make the data comparable with the microarray data. $\beta$-actin was used as a house keeping gene (endogenous control) $[70,71]$ for the analysis of data $[\Delta \Delta \mathrm{CT}=(\mathrm{CT}$ of infected/ transfected cells - CT of $\beta$-actin in infected/transfected cells) - (CT of control cells - CT of $\beta$-actin in control cells)].

\section{Abbreviations}

ARV: Avian Reovirus, CEF: Chicken Embryo Fibroblast, DEGs: Differentially expressed genes, DEHC: Differentially Expressed Highly Connected genes, DNA: Deoxyribonucleic acid, DMEM: Dulbecco's Modified Eagle's Medium, dsRNA: double-stranded RNA, ELISA: Enzyme-linked immunosorbent assay, IL: Interleukin, IPA: Ingenuity Pathway Analysis, LB Agar: Luria Bertani Agar, RNA: Ribonucleic acid, SDS-PAGE: Sodium dodecyl sulfate polyacrylamide gel electrophoresis.

\section{Author contributions}

MRP carried out the experiments. All authors analyzed the data. MRP drafted the manuscript. All authors contributed to subsequent drafts of the manuscript. All authors read and approved the final manuscript.

\section{ACKNOWLEDGMENTS}

The author is also thankful to Director IVRI, for providing necessary research facilities.

\section{Ethics statement}

The manuscript is in compliance with ethical standards.

\section{CONFLICTS OF INTEREST}

Authors declare that they have no conflicts of interest and provide the informed consent.

\section{FUNDING}

These studies were funded grant BT/PR6232/ GBD/27/392/2012 provided by department of biotechnology, government of India.

\section{REFERENCES}

1. Gouvea VS, Schnitzer TJ. Polymorphism of the genomic RNAs among the avian reoviruses. J Gen Virol. 1982; 61 (Pt 1): 87-91.

2. Wickramasinghe R, Meanger J, Enriquez CE, Wilcox GE. Avian reovirus proteins associated with neutralization of virus infectivity. Virology. 1993; 194: 688-96.

3. Glass SE, Naqi SA, Hall CF, Kerr KM. Isolation and characterization of a virus associated with arthritis of chickens. Avian Dis. 1973; 17: 415-24.

4. Ni Y, Ramig RF. Characterization of avian reovirus-induced cell fusion: the role of viral structural proteins. Virology. 1993; 194: 705-14.

5. Varela R, Martinez-Costas J, Mallo M, Benavente J. Intracellular posttranslational modifications of S1133 avian reovirus proteins. J Virol. 1996; 70: 2974-81.

6. Martinez-Costas J, Grande A, Varela R, Garcia-Martinez C, Benavente J. Protein architecture of avian reovirus S1133 and identification of the cell attachment protein. J Virol. 1997; 71: 59-64.

7. Varela R, Benavente J. Protein coding assignment of avian reovirus strain S1133. J Virol. 1994; 68: 6775-7.

8. Theophilos MB, Huang JA, Holmes IH. Avian reovirus sigma $\mathrm{C}$ protein contains a putative fusion sequence and induces fusion when expressed in mammalian cells. Virology. 1995; 208: 678-84.

9. Liu X, Kim CN, Yang J, Jemmerson R, Wang X. Induction of apoptotic program in cell-free extracts: requirement for dATP and cytochrome c. Cell. 1996; 86: 147-57.

10. Yin HS, Lee LH. Identification and characterization of RNA-binding activities of avian reovirus non-structural protein sigmaNS. J Gen Virol. 1998; 79: 1411-3.

11. García M, El-Attrache J, Riblet SM, Lunge VR, Fonseca AS, Villegas P, Ikuta N. Development and application of reverse transcriptase nested polymerase chain reaction test for the detection of exogenous avian leukosis virus. Avian Dis. 2003; 47: 41-53. 
12. Robertson MD, Wilcox GE. Avian reovirus. Veterinary Bulletin. 1986: 154-74.

13. Tang KN, Fletcher OJ. Application of the avidin-biotinperoxidase complex (ABC) technique for detecting avian reovirus in chickens. Avian Dis. 1987; 31: 591-6.

14. Li L, Giambrone JJ, Panangala VS, Hoerr FJ. Production and characterization of monoclonal antibodies against avian reovirus strain S1133. Avian Dis. 1996; 40: 349-57.

15. Liu HJ, Giambrone JJ. Characterization of a Nonradioactive Cloned cDNA Probe for Detecting Avian Reoviruses. Avian Dis. 1997; 41: 374-8.

16. Lee LH, Shien JH, Shieh HK. Detection of avian reovirus RNA and comparison of a portion of genome segment S3 by polymerase chain reaction and restriction enzyme fragment length polymorphism. Res Vet Sci. 1998; 65: 11-5.

17. Hsu CJ, Wang CY, Lee LH, Shih WL, Chang CI, Cheng HL, Chulu JL, Ji WT, Liu HJ. Development and characterization of monoclonal antibodies against avian reovirus sigma $\mathrm{C}$ protein and their application in detection of avian reovirus isolates. Avian Pathol. 2006; 35: 320-6.

18. Liu HJ, Kuo LC, Hu YC, Liao MH, Lien YY. Development of an ELISA for detection of antibodies to avian reovirus in chickens. J Virol Methods. 2002; 102: 129-38.

19. Xie Z, Qin C, Xie L, Liu J, Pang Y, Deng X, Xie Z, Khan MI. Recombinant protein-based ELISA for detection and differentiation of antibodies against avian reovirus in vaccinated and non-vaccinated chickens. J Virol Methods. 2010; 165: 108-11.

20. Yang ZJ, Wang CY, Lee LH, Chuang KP, Lien YY, Yin HS, Tong DW, Xu XG, Liu HJ. Development of ELISA kits for antibodies against avian reovirus using the sigmaC and sigmaB proteins expressed in the methyltropic yeast Pichia pastoris. J Virol Methods. 2010; 163: 169-74.

21. Smith LM, Brown SR, Howes K, McLeod S, Arshad SS, Barron GS, Venugopal K, McKay JC, Payne LN. Development and application of polymerase chain reaction (PCR) tests for the detection of subgroup J avian leukosis virus. Virus Res. 1998; 54: 87-98.

22. Dhama K, Sawant PM, Kumar D, Kumar R. Diagnostic applications of molecular tools and techniques for important viral diseases of poultry. pp. 32-40.

23. Caterina KM, Frasca S Jr, Girshick T, Khan MI. Development of a multiplex PCR for detection of avian adenovirus, avian reovirus, infectious bursal disease virus, and chicken anemia virus. Mol Cell Probes. 2004; 18: 293-8.

24. Xie Z, Peng Y, Luo S, Wang Y, Liu J, Pang Y, Deng X, Xie Z, Xie L, Fan Q, Teng L, Wang X. Development of a reverse transcription loop-mediated isothermal amplification assay for visual detection of avian reovirus. Avian Pathol. 2012; 41: 311-6.

25. Kumar D, Chauhan TK, Agarwal RK, Dhama K, Goswami PP, Mariappan AK, Tiwari AK, Mishra BP. A doublestranded probe coupled with isothermal amplification for qualitative and quantitative detection of avian reovirus. Arch Virol. 2017; 162: 979-85.

26. Olson NO, Kerr KM. Some characteristics of an avian arthritis viral agent. Avian Dis. 1966; 10: 470-6.

27. Walker ER, Friedman MH, Olson NO. Electron microscopic study of an avian reovirus that causes arthritis. J Ultrastruct Res. 1972; 41: 67-79.

28. Jones RC. Avian reovirus infections. Rev Sci Tech. 2000; 19: 614-25.

29. van der Heide L, Lutticken D, Horzinek M. Isolation of avian reovirus as a possible etiologic agent of osteoporosis ("brittle bone disease"; "femoral head necrosis") in broiler chickens. Avian Dis. 1981; 25: 847-56.

30. Sharafeldin TA, Mor SK, Bekele AZ, Verma H, Goyal $\mathrm{SM}$, Porter RE. The role of avian reoviruses in turkey tenosynovitis/arthritis. Avian Pathol. 2014; 43: 371-8.

31. Lin PY, Liu HJ, Chang CD, Chang CI, Hsu JL, Liao MH, Lee JW, Shih WL. Avian reovirus S1133-induced DNA damage signaling and subsequent apoptosis in cultured cells and in chickens. Arch Virol. 2011; 156: 1917.

32. Tang Y, Lin L, Sebastian A, Lu H. Detection and characterization of two co-infection variant strains of avian orthoreovirus (ARV) in young layer chickens using nextgeneration sequencing (NGS). Scientific Reports. 2016; 6: 24519.

33. Niu X, Wang Y, Li M, Zhang X, Wu Y. Transcriptome analysis of avian reovirus-mediated changes in gene expression of normal chicken fibroblast DF-1 cells. BMC Genomics. 2017; 18: 911.

34. Schett G, Kiechl S, Bonora E, Zwerina J, Mayr A, Axmann R, Weger S, Oberhollenzer F, Lorenzini R, Willeit J. Vascular cell adhesion molecule 1 as a predictor of severe osteoarthritis of the hip and knee joints. Arthritis Rheum. 2009; 60: 2381-9.

35. Hong S, Derfoul A, Pereira-Mouries L, Hall DJ. A novel domain in histone deacetylase 1 and 2 mediates repression of cartilage-specific genes in human chondrocytes. FASEB J. 2009; 23: 3539-52.

36. Makki MS, Haqqi TM. Histone Deacetylase Inhibitor Vorinostat (SAHA) Suppresses IL-1beta-Induced Matrix Metallopeptidase-13 Expression by Inhibiting IL-6 in Osteoarthritis Chondrocyte. Am J Pathol. 2016; 186: 2701-8.

37. Krauss H, Ueberschar S. [Structure of a new avian orphan virus]. [Article in German]. Zentralbl Veterinarmed B. 1966; 13:239-49.

38. Yin CH, Qin LT, Sun MY, Gao YL, Qi XL, Gao HL, Wang YQ, Wang XM. Antigenic analysis of monoclonal antibodies against different epitopes of sigmaB protein of avian reovirus. PLoS One. 2013; 8: e81533.

39. Hartmann C, Tabin CJ. Wnt-14 plays a pivotal role in inducing synovial joint formation in the developing appendicular skeleton. Cell. 2001; 104: 341-51.

40. Studer D, Millan C, Ozturk E, Maniura-Weber K, Zenobi-Wong M. Molecular and biophysical mechanisms 
regulating hypertrophic differentiation in chondrocytes and mesenchymal stem cells. Eur Cell Mater. 2012; 24: 118-35; discussion 135 .

41. Pelletier JP, Martel-Pelletier J, Abramson SB. Osteoarthritis, an inflammatory disease: potential implication for the selection of new therapeutic targets. Arthritis Rheum. 2001; 44: 1237-47.

42. Shi J, Schmitt-Talbot E, DiMattia DA, Dullea RG. The differential effects of IL-1 and TNF-alpha on proinflammatory cytokine and matrix metalloproteinase expression in human chondrosarcoma cells. Inflamm Res. 2004; 53: 377-89.

43. Mort JS, Billington CJ. Articular cartilage and changes in arthritis: matrix degradation. Arthritis Res. 2001; 3: 337-41.

44. Bau B, Gebhard PM, Haag J, Knorr T, Bartnik E, Aigner T. Relative messenger RNA expression profiling of collagenases and aggrecanases in human articular chondrocytes in vivo and in vitro. Arthritis Rheum. 2002; 46: 2648-57.

45. $\mathrm{Wu} \mathrm{W}$, Billinghurst RC, Pidoux I, Antoniou J, Zukor D, Tanzer M, Poole AR. Sites of collagenase cleavage and denaturation of type II collagen in aging and osteoarthritic articular cartilage and their relationship to the distribution of matrix metalloproteinase 1 and matrix metalloproteinase 13. Arthritis Rheum. 2002; 46: 2087-94.

46. Aigner T, Zien A, Gehrsitz A, Gebhard PM, McKenna L. Anabolic and catabolic gene expression pattern analysis in normal versus osteoarthritic cartilage using complementary DNA-array technology. Arthritis Rheum. 2001; 44: 2777-89.

47. Meulenbelt I, Seymour AB, Nieuwland M, Huizinga TW, van Duijn CM, Slagboom PE. Association of the interleukin-1 gene cluster with radiographic signs of osteoarthritis of the hip. Arthritis Rheum. 2004; 50: 1179-86.

48. Goldring SR. Pathogenesis of bone and cartilage destruction in rheumatoid arthritis. Rheumatology (Oxford). 2003; 42:ii11-6.

49. Nakamura I, Takahashi N, Jimi E, Udagawa N, Suda T. Regulation of osteoclast function. Mod Rheumatol. 2012; 22: 167-77.

50. Demissie S, Cupples LA, Myers R, Aliabadi P, Levy D, Felson DT. Genome scan for quantity of hand osteoarthritis: the Framingham Study. Arthritis Rheum. 2002; 46: 946-52.

51. Goumans MJ, Mummery C. Functional analysis of the TGFbeta receptor/Smad pathway through gene ablation in mice. Int J Dev Biol. 2000; 44: 253-65.

52. Richette P, Corvol M, Bardin T. Estrogens, cartilage, and osteoarthritis. Joint Bone Spine. 2003; 70: 257-62.

53. Blaney Davidson EN, Remst DF, Vitters EL, van Beuningen HM, Blom AB, Goumans MJ, van den Berg WB, van der Kraan PM. Increase in ALK1/ALK5 ratio as a cause for elevated MMP-13 expression in osteoarthritis in humans and mice. J Immunol. 2009; 182: 7937-45.

54. Pan Q, Wu Y, Lin T, Yao H, Yang Z, Gao G, Song E, Shen H. Bone morphogenetic protein-2 induces chromatin remodeling and modification at the proximal promoter of Sox9 gene. Biochem Biophys Res Commun. 2009; 379: 356-61.

55. Pan Q, Yu Y, Chen Q, Li C, Wu H, Wan Y, Ma J, Sun F. Sox9, a key transcription factor of bone morphogenetic protein-2-induced chondrogenesis, is activated through BMP pathway and a CCAAT box in the proximal promoter. J Cell Physiol. 2008; 217: 228-41.

56. Furumatsu T, Tsuda M, Taniguchi N, Tajima Y, Asahara H. Smad3 induces chondrogenesis through the activation of SOX9 via CREB-binding protein/p300 recruitment. J Biol Chem. 2005; 280: 8343-50.

57. Shi Y, Massague J. Mechanisms of TGF-beta signaling from cell membrane to the nucleus. Cell. 2003; 113: 685-700.

58. Horiki M, Imamura T, Okamoto M, Hayashi M, Murai J, Myoui A, Ochi T, Miyazono K, Yoshikawa H, Tsumaki N. Smad6/Smurf1 overexpression in cartilage delays chondrocyte hypertrophy and causes dwarfism with osteopenia. J Cell Biol. 2004; 165: 433-45.

59. van der Kraan PM, Blaney Davidson EN, Blom A, van den Berg WB. TGF-beta signaling in chondrocyte terminal differentiation and osteoarthritis: modulation and integration of signaling pathways through receptor-Smads. Osteoarthritis Cartilage. 2009; 17: 1539-45.

60. Holden P, Canty EG, Mortier GR, Zabel B, Spranger J, Carr A, Grant ME, Loughlin JA, Briggs MD. Identification of novel pro-alpha2(IX) collagen gene mutations in two families with distinctive oligo-epiphyseal forms of multiple epiphyseal dysplasia. Am J Hum Genet. 1999; 65: 31-8.

61. Kim HA, Cho ML, Choi HY, Yoon CS, Jhun JY, Oh HJ, Kim HY. The catabolic pathway mediated by Toll-like receptors in human osteoarthritic chondrocytes. Arthritis Rheum. 2006; 54: 2152-63.

62. Zhang Q, Hui W, Litherland GJ, Barter MJ, Davidson R, Darrah C, Donell ST, Clark IM, Cawston TE, Robinson JH, Rowan AD, Young DA. Differential Toll-like receptordependent collagenase expression in chondrocytes. Ann Rheum Dis. 2008; 67: 1633-41.

63. Hernandez R, Brown DT. Growth and maintenance of chick embryo fibroblasts (CEF). Curr Protoc Microbiol. 2010; $4: 4 \mathrm{I}$.

64. Kumar D, Tiwari AK, Dhama K, Bhatt P, Shrivastava S, Kumar S. Time course of apoptosis induced by infectious bursal disease virus in chicken embryo fibroblast cells. Vet Practitioner. 2011; 12: 1-8.

65. Li X, Chiang HI, Zhu J, Dowd SE, Zhou H. Characterization of a newly developed chicken 44K Agilent microarray. BMC Genomics. 2008; 9: 60.

66. Kramer A, Green J, Pollard J Jr, Tugendreich S. Causal analysis approaches in Ingenuity Pathway Analysis. Bioinformatics. 2014; 30: 523-30.

67. Chatr-Aryamontri A, Oughtred R, Boucher L, Rust J, Chang C, Kolas NK, O'Donnell L, Oster S, Theesfeld C, Sellam A, Stark C, Breitkreutz BJ, Dolinski K, et al. The BioGRID 
interaction database: 2017 update. Nucleic Acids Res. 2017; 45: D369-D79.

68. Shannon P, Markiel A, Ozier O, Baliga NS, Wang JT, Ramage D, Amin N, Schwikowski B, Ideker T. Cytoscape: a software environment for integrated models of biomolecular interaction networks. Genome Res. 2003; 13: 2498-504.

69. Schmittgen TD, Livak KJ. Analyzing real-time PCR data by the comparative C(T) method. Nat Protoc. 2008; 3: 1101-8.
70. De Boever S, Vangestel C, De Backer P, Croubels S, Sys SU. Identification and validation of housekeeping genes as internal control for gene expression in an intravenous LPS inflammation model in chickens. Vet Immunol Immunopathol. 2008; 122: 312-7.

71. Olias P, Adam I, Meyer A, Scharff C, Gruber AD. Reference Genes for Quantitative Gene Expression Studies in Multiple Avian Species. PLoS One. 2014; 9: e99678. 